\title{
WORK RESERVATION FOR THE SOUTH AFRICAN SCIENTIFIC AND ENGINEERING PROFESSIONAL FRATERNITIES
}

\author{
J. Basson \\ Be-Agile Consulting and Projects CC \\ South Africa \\ agile@jaywalk.com
}

\begin{abstract}
The Council for the Built Environment Act, Act No. 43 of 2000, the Engineering Profession Act, Act No. 46 of 2000 and the Natural Scientific Professions Act, Act No. 27 of 2003 provide for, amongst others, the establishment of juristic persons known as councils for the registration of professional, candidate and certified natural scientists, the registration of professionals, candidates and specified categories in the engineering profession, and work reservation for all these categories of registered persons. The question arises: "Which criteria must be met for the scientific and engineering professions to claim the right to reserve identified work for the categories of registered persons without infringing the constitutional rights of any person in South Africa to choose and practice his or her trade, occupation or profession freely?” The criteria for identifying and defining work for reservation are discussed, and a few hypothetical examples are given to show that the whole topic is not a straightforward matter of passing legislation.
\end{abstract}

\section{OPSOMMING}

Die Wet op die Raad vir die Bou-omgewing 43 van 2000, die Wet op die Ingenieursprofessie 46 van 2000 en die Wet op Natuurwetenskaplike Professies 27 van 2003 maak onder meer voorsiening vir die skep van juridiese persone bekend as rade, vir die registrasie van professionele, kandidaat en gesertifiseerde natuurwetenskaplikes, die registrasie van professionele, kandidaat en spesifieke kategorieë in die ingenieursprofessie, en vir werkvoorbehouding vir al hierdie kategorieë van geregistreerde persone. Die vraag ontstaan: “Aan welke kriteria moet voldoen word alvorens die wetenskaplike- en ingenieursprofessies regtens aanspraak kan maak om bepaalde werke toe te eïen vir die kategorieë van geregistreerde persone sonder inbreukmaking op die menseregte van enige persoon in Suid-Afrika om sy of haar beroep of professie van eie keuse te kan beoefen?” Die kriteria vir die identifisering en beskrywing van die werk vir reservering word bespreek. 'n Aantal hipotetiese gevalle word bespreek om aan te dui dat die problem van werkreservering vele fasette het en nie bloot opgelos kan word deur die aanname van wetgewing nie. 


\section{INTRODUCTION}

The Council for the Built Environment Act, Act No. 43 of 2000, the Engineering Profession Act, Act No. 46 of 2000 and the Natural Scientific Professions Act, Act No. 27 of 2003 provide for, amongst others, the establishment of juristic persons known as councils, for the registration of professional, candidate and certified natural scientists, the registration of professionals, candidates and specified categories in the engineering profession, and work reservation (also known as "function reservation") for all these categories of registered persons.

Section 18(2) of the Engineering Profession Act states that a person may not practise in any of the engineering profession categories unless he or she is registered in that category. A person may practise in a consultancy capacity in the category in which he or she is registered.

Section 26(3)(a) of this Act further states that a person who is not registered in terms of this Act may not perform any kind of work identified for any category of registered persons. This subsection does not prohibit any person from performing work identified in terms of section 26(3)(a), if such work is performed in the service of or by order of and under the direction, control, supervision of or in association with a registered person entitled to perform the work identified and who must assume responsibility for any work so performed [section 26(4)].

A person contravening section 18(2) is guilty of an offence [section 41(1)]. A person convicted of an offence in terms of section 18(2) may be liable to a fine equal to double the remuneration received by him or her for work done in contravention of section 18(2), or to a fine equal to the fine calculated according to the ratio determined for three years imprisonment in terms of the Adjustment of Fines Act, Act No. 101 of 1991 [section 41(3)].

This Act binds the State [section 44].

The Adjustment of Fines Act, Act No. 101 of 1991, itself does not directly spell out the type and ambit of work reservation for the different engineering profession categories. One may assume that the type and ambit of work to be reserved for the different engineering profession categories will in due course be published as a regulation.

Under section 1, "Definitions", the Act does not define "engineering”, “engineer" and "professional engineer", "practise" or "consulting capacity". "Actively practise" is defined as "practising" on an ongoing basis in one of the professional engineering categories and includes a person qualified in the engineering profession who is employed by any sphere of government or an educational institution. Neither is "engineering profession” nor "educational institution" defined. The phrase "actively practise" does not again appear in this Act. It is accordingly not clear what the intent of the legislature was in defining "actively practice", as section 18(2) merely states that a person may not practice (not "actively practise") in any of the categories reserved for the professions. 
Botha [2005] points out that words and text used in legislation pertaining to specific trades and professions that have a specific meaning in that field must be given their specialised meaning within the context of the legislation and the Constitution.

Section 18(2) of the Natural Scientific Professions Act, Act No. 27 of 2003, states that a person may not practise in any of the fields of practice listed in Schedule 1 (of the Act), unless he or she is registered in a section 18(1) category, namely as a "professional natural scientist", or a "candidate natural scientist" or a "certified natural scientist”. Only a professional natural scientist, a candidate natural scientist or a certified natural scientist may practise in a consulting capacity in the category in which he or she is registered. These categories are not subdivided, as is the case with the Engineering Profession Act.

Section 27(3)(a) of this Act states that a person who is not registered in terms of the Act may not perform any kind of work identified for any category of registered persons in terms of this Act. Section 27(5) makes provision that a person registered in terms of the Engineering Profession Act of 2000 may perform those elements of the natural scientific profession which are essential for the practising of his or her profession, if his or her education, training and experience render him or her competent to perform that work.

In terms of section 27(4) any person not registered in terms of this Act may perform work identified in terms of section 27(3), if such work is performed in the service of or by order of and under the direction, control and supervision of, or in association with, a registered person entitled to perform the identified work and who must assume responsibility for any work so performed.

A person contravening section 27(3)(a) [note, not section 18(2)] is guilty of an offence [section 41(1)]. A person convicted of an offence in terms of section 27(3)(a) is liable to a maximum fine equal to double the remuneration received by him or her for work done in contravention thereof, or to a maximum fine equal to the fine calculated according to the ratio determined for three years imprisonment in terms of the Adjustment of Fines Act, Act No. 101 of 1991 [section 41(3)].

This Act also binds the State, except as far as the State provides forensic science services [section 43].

Schedule 1 of this Act lists the "fields of practice" reserved for the "professional natural scientist", "candidate natural scientist” and "certified natural scientist". They are Agricultural Science, Animal Science, Biological Science, Chemical Science, Material Science, Natural Science, Education Science, Physical Science, etc.

Under section 1, "Definitions", the Natural Scientific Professions Act does not provide definitions for "science", "scientist" and "professional scientist", "practise", "field of practice" or "consulting capacity". The phrase "actively practise" is not defined in this Act, unlike in the Engineering Profession Act. Neither are concepts such as "the field of Agricultural Science" and similar phrases listed in Schedule 1 defined. 
This study does not focus on the issues of legislated affirmative action measures taken to address the economic imbalances under the political dispensation prior to 1994, as embodied in, for instance, the Employment Equity Act, Act No. 55 of 1998 and the Broad-based Black Economic Empowerment Act, Act No. 53 of 2003.

\section{THE NEED FOR STATUTORY REGULATION OF THE SCIENTIFIC AND ENGINEERING PROFESSIONS}

The debate on the need for statutory regulation of the scientific and engineering professions has come a long way. It is not the purpose of this article to elaborate on the chronological developments leading to the enactment of the Council for the Built Environment Act, Act No. 43 of 2000, the Engineering Profession Act, Act No. 46 of 2000 and the Natural Scientific Professions Act, Act No. 27 of 2003, and the successes or failures of implementation of past legislation and regulations pertaining to work reservation [4].

Some key arguments in favour of a statutory regulatory framework relating to work reservation centre around the following arguments [4, 5]:

a) To ensure protection of the health, safety and pecuniary interests of the public through the effective and realistic reservation of work;

b) The achievement of appropriate standards in a profession is of public interest since there is then a formal basis for the objective judging of the suitability of a particular person to undertake specific work; and

c) To promote and maintain sustainable built and natural environments.

It is the view of the author of this article that the issue of identification and implementation of work reservation could prove to be the Achilles heel of implementation of the Council for the Built Environment Act, the Engineering Profession Act and the Natural Scientific Professions Act as set out in this study.

\section{THE CONSTITUTION OF THE REPUBLIC OF SOUTH AFRICA}

The Bill of Rights as enshrined in the Constitution of the Republic of South Africa, Act No. 108 of 1996, sets out the rights of all the people of South Africa and affirms the democratic values of human dignity, equality, the advancement of human rights and freedom.

For the purpose of the topic of this article and for completeness' sake, the following rights in the Bill of Rights are highlighted:

a) Section 9(1): Everyone is equal before the law and has the right to equal protection and benefit of the law.

b) Section 10: Everyone has inherent dignity and the right to have their dignity respected and protected. 
c) Section 16: Everyone has the right of freedom of expression, which includes academic freedom and freedom of scientific research [Underlined for emphasis].

d) Section 18: Everyone has the right of association.

e) Section 22: Every citizen has the right of freedom to choose his or her trade, occupation or profession. The practise of such a trade, occupation or profession may be regulated by law.

f) Section 24: Everyone has the right to an environment that is not harmful to their health or well-being; and to have the environment protected for the benefit of present and future generations within the reasonable context of the promotion of justifiable economic and social development.

g) Section 36(1): The rights in the Bill of Rights may be limited only in terms of law of general application to the extent that the limitation is reasonable and justifiable in an open and democratic society based on human dignity, equality and freedom, taking into account all relevant factors, including (i) the nature of the right; (ii) the importance of the purpose of the limitation; (iii) the nature and extent of the limitation; (iv) the relation between the limitation and its purpose; and (v) less restrictive means to achieve the purpose.

h) Section 36(2): Except as provided in section 36(1) or in any other provision in the Constitution, no law may limit any right entrenched in the Bill of Rights.

i) Section 35(3)(a): Every accused person has a right to a fair trial, which includes the right to be informed of the charge with sufficient detail to answer it.

j) Section 35(3)(1): Every accused person has the right to a fair trial, which includes the right not to be convicted for an act or omission that was not an offence under either national or international law at the time it was committed or omitted.

k) Section 35(3)(n): Every accused person has the right to a fair trial, which includes the right to the benefit of the least severe of the prescribed punishments if the prescribed punishment for the offence has been changed between the time that the offence was committed and the time of sentencing.

\section{THE HUMAN RIGHT OF DIGNITY AND WORK RESERVATION}

In the $S$ v Makwanyana and Another [10], Constitutional Court Judge Chaskalson made the following statement with reference to the interim Constitution, which statement equally applies to the present Constitution:

"The rights to life and dignity are the most important of all human rights, and the source of all other personal rights in chapter 3. By 
committing ourselves to a society founded on the recognition of human rights we are required to value these two rights above all others."

In the same case, Constitutional Court Judge O’Regan said the following:

"The importance of dignity as a founding value of the new Constitution cannot be overemphasized. Recognising a right to dignity is an acknowledgement of the intrinsic worth of human beings: human beings are entitled to be treated as worthy of respect and concern. This right therefore is the foundation of many of the other rights that are specifically entrenched."

In the appeal case of Minister of Home Affairs and Others $v$ Watchenuka and Another [9] that served in the Supreme Court of Appeal, the appeal concerned the rights of asylum seekers and in particular the right of an asylum seeker to take up employment or to study in South Africa where he or she is seeking asylum.

In this case, Judge Appellate Nugent made the following statement:

"The freedom to engage in productive work - even where that is not required in order to survive - is indeed an important component of human dignity, as submitted by the respondents' counsel, for mankind is pre-eminently a social species with an instinct for meaningful association. Self-esteem and the sense of self-worth - the fulfillment of what it is to be human - are most often bound up with being accepted as socially useful. But the protection even of human dignity - that most fundamental of constitutional values - is not absolute and section 36 of the Bill of Rights recognises that it may be limited in appropriate circumstances. It may be limited where the limitation is of general application and is 'reasonable and justifiable in an open and democratic society based on human dignity, equality and freedom taking into account all relevant factors. But as pointed out by the United States Supreme Court over a century ago in Nishimura Ekiu $v$ The United States: 142 US 651 (1892) at page 659. This passage as it is cited in Tribe American Constitutional Law $2^{\text {nd }}$ ed at page 358 was cited with approval in the Certification judgment referred to in para [30] at para [21] fn 31: 'It is an accepted maxim of international law, that every sovereign nation has the power, as inherent in sovereignty, and essential to self-preservation, to forbid the entrance of foreigners within its dominions, or to admit them only in such cases and upon such conditions as it may see fit to prescribe.' "'

Judge Appellate Nugent then added the following qualification:

"But where employment is the only reasonable means for the person's support other considerations arise. What is then in issue is not merely a restriction upon the person's capacity for self-fulfillment, but a restriction upon his or her ability to live without positive humiliation and 
degradation. For it is not disputed that this country, unlike some other countries that receive refugees, offers no State support to applicants for asylum. Thus a person who exercises his or her right to apply for asylum, but who is destitute, will have no alternative but to turn to crime, or to begging, or to foraging. I do not suggest that in such circumstances the State has an obligation to provide employment - for that is not what is in issue in this appeal - but only that the deprivation of the freedom to work assumes a different dimension when it threatens positively to degrade rather than merely to inhibit the realization of the potential for selffulfillment.

In my view, there is no justification for limiting beyond that degree the protection that is afforded in section 10. As pointed out in Makwanyane (supra at para [102]), it is for the party relying upon the limitation to satisfy a court that the limitation is justified and not for the party challenging it to show that it was not justified." [underlined for emphasis.]

\section{THE PRINCIPLE OF LEGALITY}

Section 41(1) of the Engineering Profession Act states that a person contravening section 18(2) of the Act is guilty of an offence. Similarly section 41(1) of the Natural Scientific Professions Act states that a person contravening section 27(3)(a) of the Act is also guilty of an offence.

In the light of the two sections 41(1) above and for the sake of completeness, the author wishes to highlight the importance and need to clearly define the work to be reserved for the scientific and engineering fraternities.

The principle of legality dictates amongst others that no accused may be found guilty of a crime and sentenced unless the type of conduct the accused is being charged with has been declared by law as a crime in reasonably clear terms before the crime was committed. Furthermore, the principle determines that the court must not have to expand the meaning of the words and concepts in the definition of the crime to bring the conduct of the accused within the ambit of the definition of the crime [1].

The essence of the principle of legality is captured in section 35(3) of the Constitution: A person has the right to a fair trial.

The ius certum principle dictates that crimes must in general be formulated clearly and not vaguely.

The ius strictum principle dictates that a court must interpret the definition of a crime narrowly rather than in the wide sense. The people must be in a position to establish with reasonable ease what the law expects of them in order not to commit a crime.

One must remember that the written word may lend itself to different interpretations. Language is not an exact science and not a perfect vehicle of communication. 
However, the definition of the crime must be reasonably clear.

With reference to the $S v$ Lavhengwa case [2] and the National Coalition for Gay and Lesbian Equity v Minister of Justice case [3], Snyman [2002] holds the view that, based on a person's right to a fair trial and the "void-for-vagueness" rule, it is possible and even probable that vaguely defined crimes in legislation may be declared null and void. This argument also applies to broad and vague "blanket" or “ensnare net” crime definitions [2, 3].

In order to be found criminally liable of contravening section 18(2) of the Engineering Profession Act or section 27(3) of the Natural Scientific Professions Act, certain requirements must be met as discussed in the section below.

\section{ELEMENTS OF CRIMINAL LIABILITY IN A NUTSHELL}

All the requirements that must be met for criminal liability to apply are briefly the following [1]:

a) The accused must have committed an act or an omission.

b) The act or omission committed by the accused must meet the description or requirements for liability for the crime set by the law prior to the commitment of the act or omission.

c) The conduct of the accused must be unlawful (there is no justification for the act or omission).

d) Culpability, meaning that in the eyes of the law there is ground for blaming the accused personally for his or her unlawful act or unlawful omission.

The onus lies with the state to prove beyond reasonable doubt that the conduct of the person being accused of committing the crime meets the definitional elements of the crime and that the act or omission of the accused was unlawful.

The question may at this stage be rightfully asked: "How often have people, who were not registered in terms of the Engineering Profession Act or the Natural Scientific Professions Act and having performed work reserved for those categories of registered persons, been prosecuted?”

A survey of South African law reports revealed no information of any court cases whereby a person, unregistered in terms of any South African engineering profession act or natural scientific profession act, stood trial for having performed work reserved for either the engineering or natural science professions. The future will show to what extent the scientific and engineering fraternity will enforce compliance with the Engineering Profession Act or the Natural Scientific Professions Act pertaining to work reservation for these professions. 


\section{THE ISSUE}

In reserving work for the categories of registered persons as set out in the Council for the Built Environment Act, the Engineering Profession Act and the Natural Scientific Professions Act the following questions are rightly posed:

a) Does the reservation of the particular identified work for a particular category of registered persons unreasonably and unjustifiably limit any human rights of any people in South Africa, and in particular the right of freedom to choose their trade, occupation or profession?

b) Do the Engineering Profession Act, the Natural Scientific Professions Act and related regulations reasonably clearly define the definitions of the crime of contravening section 18(2) of the Engineering Profession Act or section 27(3)(a) of the Natural Scientific Professions Act?

c) Are people in South Africa in a position to establish with reasonable ease what the law prescribes in regard to work that is reserved for the different categories of the scientific and engineering professions?

The issue may thus be formulated as follows: "What criteria must be met for the scientific and engineering professions to claim the right to reserve identified work for the categories of registered persons without infringing on the constitutional rights of any South African citizen to choose and practise his or her trade, occupation or profession freely?”

\section{THE MORAL ARGUMENT}

There is also a moral angle to the issue of work reservation for the South African scientific and engineering professional fraternities.

The world population is currently more than 6 billion. Indications are that by 2050 the population will be 9 billion and will stabilise at about 10 billion by 2200 . By 2006 one in every two people in the world will be urbanised [7].

Garelli [2004] points out that "the world is undergoing an unprecedented explosion in [manufacturing] productivity based on new management methods, such as quality, automation and technology. However, this is not all there is to it. Productivity gains are further boosted by globalization of business and especially by direct investments". On the down-side, there is a worldwide increase in the number of job losses.

Korten [1990] states as follows: "The endless expansion of economic output can no longer be viewed as a panacea for what ails human society. Growth is an answer only to the extent that it is preceded by a fundamental transformation of structures and values to ensure that it will be a just, sustainable and inclusive growth - a profoundly different kind of growth than the growth we have known.” [underlined for emphasis]. 
Hence, people should not be sidelined from participating in economic growth by a system of unreasonable work reservation for the scientific and engineering fraternities.

It is my view that no country or community can live in peace and prosperity with masses of jobless, destitute, de-humanised people on its borders or around its cities turning to crime, begging or foraging.

In light of the above, the scientific and engineering fraternity has a moral obligation to do serious soul-searching when identifying and claiming work for statutory reservation for the different categories of the scientific and engineering professions.

\section{CRITERIA FOR IDENTIFYING AND DEFINING WORK FOR RESERVATION}

The author of this article does not claim to have a complete set of criteria for work reservation to hand.

The following criteria may be considered in identifying and defining the work for reservation for the different categories of registered persons:

a) That the work reservation must not unreasonably and unjustifiably limit the right of freedom of any person in South Africa to choose and practise his or her trade, occupation or profession; and

b) That any person in South Africa must be in a position to establish with reasonable ease what the law prescribes in regard to work that is reserved by law for the different categories of the scientific and engineering professions.

The statement of Judge Appellate Nugent in Minister of Home Affairs and Others $v$ Watchenuka and Another [9] is again highlighted: “... it is for the party relying upon the limitation to satisfy the court that the limitation is justified and not for the party challenging it to show that it was not justified."

In the case of work reservation in terms of the three Acts considered here, the onus will be on the Council for the Built Environment, the Engineering Council of South Africa or the South African Council for Natural Scientific Professions, as the case may be, to convince a court of law that the work reservation is not unreasonable and is justified.

\section{A FEW HYPOTHETICAL CASES OF IMPLEMENTATION OF WORK RESERVATION}

A few hypothetical examples of implementation of work reservation may be considered to stimulate thought on the matter.

Section 18(2) of the Natural Scientific Professions Act states that an unregistered person may not practise in the field of practise listed in Schedule 1 of the Act. Does 
this mean that an innovative farmer may not experiment on his or her own by crossing two or more cattle breeds for competitive milk or meat production? Would this amount to practising "animal science" reserved for the natural scientific profession? Similarly, may a farmer henceforth not hybridize flowers for the world flower market - would this amount to the practising of "botanical science"?

How many university engineering faculties include in their curricula training how to correctly wire an ordinary three-point $15 \mathrm{~A} / 240 \mathrm{~V}$ plug to ensure that the earth lead is the last lead to be pulled off the earth pin and that the neutral and live wires may not be interchanged? Does this mean that the wiring of all these plugs must be done by a registered person or under the supervision of a registered person?

Will a registered civil engineer with only two or three years' experience in the civil engineering field before registration have the right to design and consult on the building of dams, bridges and other super building structures? Alternatively, will it be required of registered civil engineers to demonstrate their competency as specialists in high-risk undertakings such as the building of dams, bridges or other specific super building structures as the case may be? Similar arguments apply to the electrical / electronic engineer. Does one, as an electrical / electronic engineer, need to specialise and demonstrate additional competency in the design and building of, for instance, high safety risk high-frequency induction heaters? If so, are there sufficient competent specialists in the field of high-frequency induction in a country such as South Africa to act as peer reviewers to establish whether an applicant for registration is competent in such a specialised field? Or will it suffice to be merely a registered electrical / electronic engineer with only two or three years' experience?

In exercising one's freedom to do scientific research, how will this right be curtailed by work reservation for the scientific and engineering professions?

If one wishes to teach science and mathematics, does this mean one has to be registered to practise "mathematics education science"? Does this requirement apply to schools and / or "educational institutions"? In addition, would "educational institution" mean an educational institution having a department, school or faculty of natural science in terms of section 13(a) of the Engineering Profession Act?

Will all work of a scientific and engineering nature be reserved for these professions, and if not, what will constitute the cut-off boundary of the work reservation? These are the teasing questions to be addressed by the Council for the Built Environment, the Engineering Council of South Africa and the South African Council for Natural Scientific Professions, indeed by every member of the scientific and engineering fraternity.

\section{THE ROLE OF MEMBERS OF THE SCIENTIFIC AND ENGINEERING FRATERNITY IN IDENTIFYING AND DEFINING WORK FOR RESERVATION}

The Council for the Built Environment Act, the Engineering Profession Act and the Natural Scientific Professions Act set out the duties of the different Councils and the 
processes to be followed in identifying and publishing the work for reservation.

Section 20(1) of the Council for the Built Environment Act requires that the Council for the Built Environment must consult with any person, body or industry that may be affected by the identification of work for reservation.

Section 26(1) of the Engineering Profession Act requires that the Engineering Council of South Africa must consult with all voluntary associations recognised by this Council, any person, any body, or any industry that may be affected by any laws relating to the built environment regarding the identification of the type of engineering work which may be performed by persons registered in any of the categories referred to in section 18 of this Act.

Similarly, the South African Council for Natural Scientific Professions must consult with all voluntary associations regarding the identification of the type of natural scientific work that may be performed by registered persons [section 27(1)]. No mention is made of compulsory consultation with any person, body or industry that may be affected by the identification of work for reservation.

The question arises: "Who decides which person / body / industry / voluntary association may be affected?"

\section{CONCLUSIONS}

In studying the Council for the Built Environment Act, the Engineering Profession Act and the Natural Scientific Professions Act, one wonders whether the cart was not put before the horse by having these acts legislated before having determined the precise areas of work reservation and precise criteria for the selection of work for reservation.

The collective wisdom of the scientific and engineering fraternity and legal specialists will be needed to:

a) Document the criteria that must be met for the scientific and engineering professions to claim the right to reserve identified work for the categories of registered persons without infringing the constitutional rights of any South African citizen to choose and practice his or her trade, occupation or profession freely;

b) Identify and document the work for reservation in such clear terms that any person in South Africa will be in a position to establish with reasonable ease what the law prescribes regarding which work is reserved for the different categories of the scientific and engineering professions;

c) Consider the need to enhance job creation without stifling the economy and entrepreneurship with excessive work reservation; and

d) Capture work reservation within the context of a value system that ensures a 
just, sustainable and inclusive growth for all to live with human dignity.

Scientists and engineers, who expect legislated work reservation, cannot expect the Council for the Built Environment, the Engineering Council of South Africa and the South African Council for Natural Scientific Professions and the legal fraternity to resolve this problem of definition of criteria for identifying and describing which kind of work is reserved. If the science and engineering professions do not of their own accord come forward to the councils with clear motivated evidence for the need for work reservation, then let us not deal with work reservation under the banner of public heath and safety and environment protection. South Africa's current statutory laws and its common law of delict address the issues of protection of the health and safety of its citizens and the protection of the environment. If need be, statutory laws can be legislated or the common laws further developed by our courts through their decisions over time to address particular unforeseen health, safety and environmental risks. However, the law is not a panacea that will assist human society, rather we need to guard against over-legislation that may lead to the stifling of entrepreneurship and wealth creation.

Lastly, it is the view of the author that all interested persons in South Africa must, irrespective of whom the respective Councils believe may be affected by work reservation, be approached to comment on any work reservation prior to formal legal reservation.

\section{REFERENCES}

[1] Snyman, C.R., 2002. Criminal Law, $4^{\text {th }}$ Edition, Butterworths.

[2] S v Lavhengwa, 1996, (2) SACR 453 (W).

[3] National Coalition for Gay and Lesbian Equality and Another v Minister of Justice and Others, 1998 (2). SACR 102 (WLD).

[4] Policy Document on the Statutory Regulation of the Built Environment Professions, June 1999, South African Department of Public Works, Pretoria.

[5] Licensing and the UK Engineering Profession, A Review. May 2003, Eras Ltd., Cranfield Place, London NW6 3BT, UK.

[6] Korten, D.C., 1990. Getting to the $21^{\text {st }}$ Century - Voluntary Action and the Global Agenda, Kumarian Press Inc., USA.

[7] The World at Six Billion, 1999, Population Division, Department of Economic and Social Affairs, United Nations Secretariat.

[8] Garelli, S., 2004. Executive Summary - The World Competitiveness Landscape in 2004: Hot Issues, IMD World Competitiveness Yearbook 2004, Institute for Management Development, Lausanne, Switzerland.

[9] Minister of Home Affairs and Others $v$ Watchenuka and Another, 2004 (4) SA 326 (SCA).

[10] S v Makwanyana and Another, 1995 (3) SA 391 (CC).

[11] Botha, C., 2005. Statutory Interpretation - An introduction for students, $4^{\text {th }}$ Edition, Juta \& Co Ltd, Cape Town. 